\title{
EARLY MIOCENE MEGACRICETODON AND DEMOCRICETODON (CRICETIDAE, RODENTIA) FROM THE VALLÈS-PENEDÈS BASIN (CATALONIA)
}

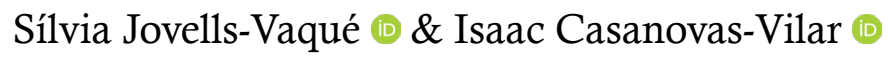

Institut Català de Paleontologia Miquel Crusafont, Universitat Autònoma de Barcelona, Cerdanyola del Vallès, Spain. silvia.jovells@icp. cat; isaac.casanovas@icp.cat

\author{
KEYwORDS: \\ early Miocene; \\ Democricetodon; \\ Megacricetodon; \\ Biostratigraphy; \\ Iberian Peninsula.
}

\section{Bullet-Points Abstract}

- Democricetodon and Megacricetodon species are present during the early Miocene in the Vallès-Penedès Basin.

- The first occurrence of both genera Democricetodon and Megacricetodon in the Basin mark the beginning of the MN4.

- These species are key for stablish a high-resolution local biozonation and correlated to other European Basins.

\section{INTRODUCTION}

The cricetodontine genera Democricetodon Fahlbusch, 1964 and Megacricetodon Fahlbusch, 1964 are the first modern cricetids to disperse into Europe. Democricetodon is first recorded during the late MN3, whereas $\mathrm{Me}$ gacricetodon does not appear until MN4 (Agustí et al., 2001; Hilgen et al., 2012). These cricetids dispersed after the extinction of the archaic cricetids Pseudocricetodon (Thaler, 1969) and Eucricetodon (Thaler, 1966), which had characterized the Oligocene, and quickly became dominant in the rodent faunas. Megacricetodon and Democricetodon have been widely used in biostratigraphical and biochronological scales for the early and middle Miocene all along Europe, the occurrence of their different species being the basis for the definition of high-resolution local biozones (e.g. Van der Meulen et al., 2012; Kälin \& Kempft, 2009; Prieto \& Rummel, 2016). In this work, we review the early Miocene record of Megacricetodon and Democricetodon in the Vallès-Penedès Basin (Catalonia, NE Iberian Peninsula). The early Miocene part of the record of this basin has been little studied in comparison with middle to late Miocene one.

\section{Materials AND Methods}

Between 2011 and 2017 the early Miocene outcrops were systematically surveyed resulting in the discovery of several new localities (Casanovas-Vilar et al., 2016). In addition, some of the classical sites were sampled using modern methods, including screen-washing, thus allowing for the recovery of remarkably rich microvertebrate samples (Jovells-Vaqué et al., 2018). The described material is housed at the Institut Català de Paleontologia Miquel Crusafont in Sabadell (Barcelona, Spain).

\section{Systematic Palaeontology}

Order Rodentia Bowdich, 1821

Family Cricetidae Fischer, 1817

Genus Democricetodon Fahlbusch, 1964

Democricetodon hispanicus Freudenthal, 1967

Figs. 1A-D

The $\mathrm{m} 1$ present a characteristic bean-shaped anteroconid. The anterior valleys of the lower teeth are closed and reduced. The mesolophid varies from long to short in $\mathrm{m} 1$ and $\mathrm{m} 2$ (Figs. 1B-C) but is completely absent in the $\mathrm{m} 3$. This ridge is more frequently short to medium length, being generally longer in the $\mathrm{m} 1$ than $\mathrm{m} 2$. The sinusid is wide and slightly proverse in the $\mathrm{m} 1$ and $\mathrm{m} 2$, while in $\mathrm{m} 3$ is moderately retroverse. The M1 show a simple round anterocone (Fig.1A). The mesoloph varies from short to medium length in $\mathrm{M} 1$ and M2. The anterosinus is reduced in M2 and M3 due to the reduction of the anteroloph.

Democricetodon cf. decipiens Freudenthal \& Daams, 1988

In Vilobí del Penedès and les Escletxes del Papiol sites besides D. hispanicus a second, larger species of Democricetodon is represented by a few specimens. These fit within the size range of Democricetodon decipiens. In addition they show some of the diagnostic traits of this species such as the presence of shorter mesolophs/ids than D.hispanicus.

Democricetodon cf. moralesi Van der Meulen et al., 2003

Fig. 1E 


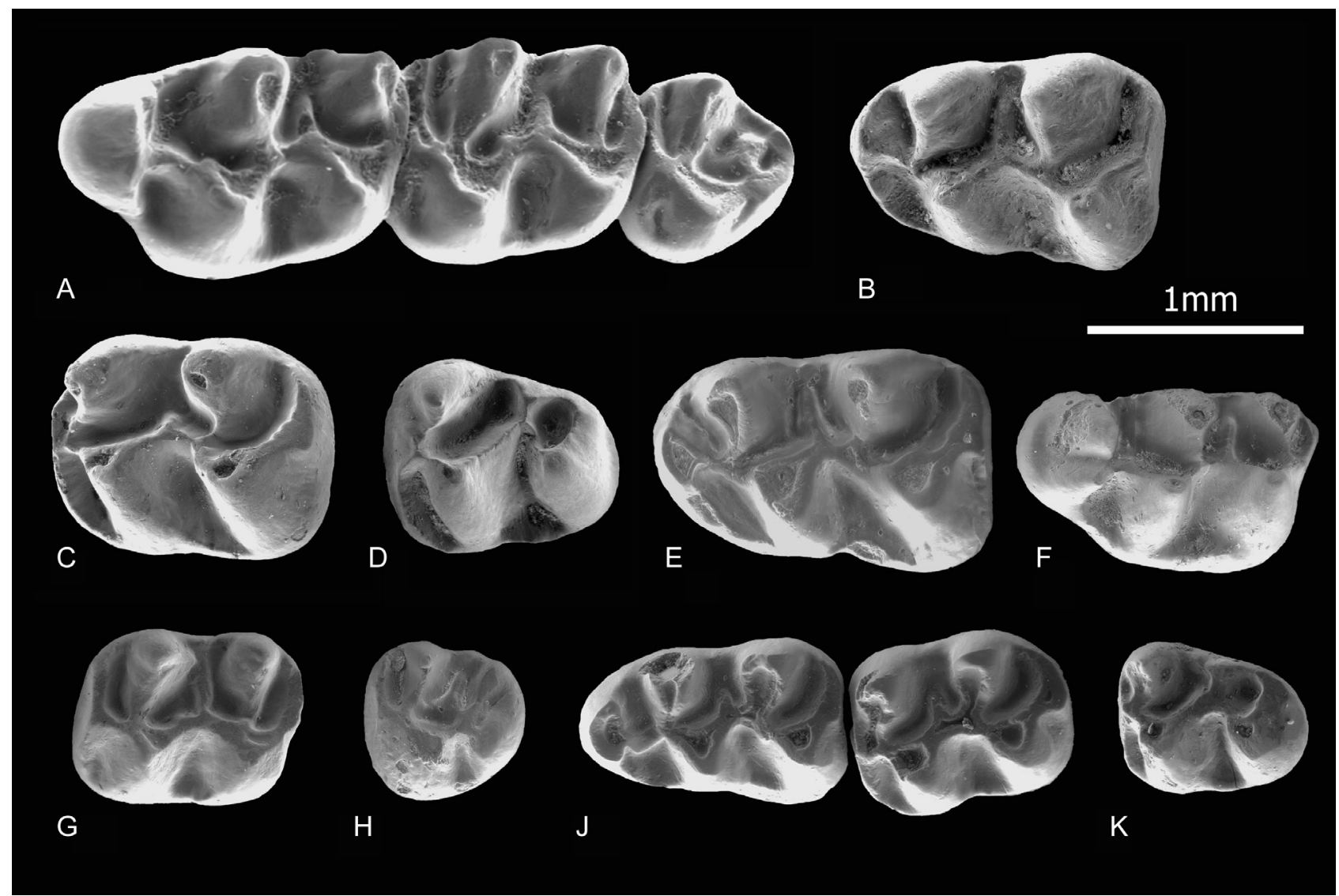

Fig. 1. Scanning electron microscope (SEM) micrographs of the Cricetidae from els Casots site. Modified from Jovells-Vaqué et a1. 2017. Democricetodon hispanicus Freudenthal, 1967 - A, IPS 45008, right M1-M3 (reversed); B, IPS 45049, right m1 (reversed); C, IPS 45059, right m2 (reversed); D, IPS 19473, left m3. Democricetodon cf. moralesi Van der Meulen et al., 2003- E, IPS 45052, left m1. Megacricetodon primitivus (Freudenthal, 1963) - F, IPS 44939 right M1 (reversed); G, IPS 44961, left M2; H, IPS 19479 left M3; I, IPS 44950, right m1-m2 (reversed); J, IPS:44992 right m3 (reserved).

An even larger-sized Democricetodon species is present at els Casots and la Riera del Morral sites. At els Casots it cooccurs with $D$. hispanicus, whereas at Riera del Morral it represents the only recovered species. This species is larger than both $D$. hispanicus and $D$. decipiens, the few recovered specimens fitting within the range size of $D$. moralesi. The recovered M2 share with $D$. moralesi the presence of a double protolophule in the M2 as well as a short to medium-sized mesolophs/ ids.

\section{Democricetodon cf. gracilis Fahlbusch, 1964}

Finally, yet another species is present at some sites (els Casots, Vilobí del Penedès, Sant Mamet), although it is represented by very few specimens. These are distinguished because of their small size, below the size range of $D$. hispanicus.

\section{Genus Megacricetodon Fahlbusch, 1964}

Megacricetodon primitivus (Freudenthal, 1963)

\section{Figs. 1F-J}

Small-sized species of Megacricetodon. The m1 present a simple rounded anteroconid. The lingual antero- lophid is reduced, thus resulting in a narrow anterosinusid. The mesolophid ranges from long to short, but is more frequently short to medium lenght. The M1 (Fig. 1F) shows a deeply split anterocone with a well-defined platform-like anterior cingulum on its base. The protolophule is simple in the M1 and M2. The mesoloph ranges from long to medium length.

\section{Discussions AND Conclusion}

The genera Democricetodon and Megacricetodon first appear simultaneously in MN4 sites of the Vallès-Penedès Basin. In other European basins, such as the Calatayud-Montalbán Basin or the Swiss Molasse Basin, Democricetodon is recorded earlier, during the late MN3 (Kälin \& Kempf, 2009; Van der Meulen et al., 2012). The situation seen in the Vallès-Penedès might be attributable to the lack of late MN3 sites (correlated to zone B of Calatayud-Montalbán Basin, the type area of the Aragonian mammal age). The species identified in the Vallès-Penedès sites are also recorded in the $\mathrm{Ca}$ latayud Montalbán Basin, although they are not coetaneous, $D$. hispanicus being restricted to local zone B and $M$. primitivus first occurring in local subzone $\mathrm{Ca}$ (Van der Meulen et al., 2012). Local subzone Ca is 
also characterized by the coexistence of the eomyids Ligerimys florancei (Stehlin \& Schaub, 1951) and Ligerimys ellipticus (Daams, 1976), which also co-occur in all the Vallès-Penedès sites except els Casots, Vilobí del Penedès and Sant Mamet. These could indicate that the latter localities might be somewhat younger. The fact that they have delivered additional, larger-sized Democricetodon species, Democricetodon cf. decipiens and Democricetodon cf. moralesi, supports this interpretation. $D$. decipiens characterizes subzone $\mathrm{Ca}$ in the Aragonian type area, whereas $D$. moralesi is diagnostic of zone $\mathrm{Cb}$. In the Vallès-Penedès Basin the cricetid succession is not the same, $D$. hispanicus persists for a longer time (well into zone $\mathrm{C}$ ) and a clear distinction between subzones $\mathrm{Ca}$ and $\mathrm{Cb}$ on the basis of the cricetid species is not possible. On the other hand, the small-sized Democricetodon cf. gracilis is not present in the Calatayud-Montalbán Basin, being characteristic of Central Europe (Swiss and Bavarian Molasse basins; see Abdul Aziz et al., 2008; Kälin \& Kempf, 2009). Therefore, the Vallès-Penedès cricetid record includes taxa mostly showing affinities with other Iberian basins as well as a minor proportion of forms that evidence connections with Central Europe.

\section{ACKNOWLEDGEMENTS}

This research has been funded by the Agencia Estatal de Investigación from the Spanish Ministerio de Economía, Indústria y Competitividad and the Agencia Estatal de Investigación (AEI) from Spain/European Regional Development Fund of the European Union (project CG2017-82654-P, CG2016-76431-P, RYC-2013-12470 research contract to ICV), by the Agència de Gestió d'Ajuts Universitaris i de Reserca of the Generalitat de Catalunya (2018 FI B1 00201 pre-doctoral grant to SJV), and by the CERCA programme of the Generalitat de Catalunya (project 2014/100584) and the National Geographic Society (grant number 9645-15). This work has been performed by researchers from the consolidated research group "Neogene and Quaternary Vertebrate Paleobiodiversity (NQVP)" (2017 SGR 86 GRC) of the Generalitat de Catalunya.

\section{REFERENCES}

Abdul Aziz H., Böhme M., Rocholl A., Zwing A., Prieto J., Wijbrans J. R., Heissig K. \& Bactadse V. (2008). Integrated stratigraphy and ${ }^{40} \mathrm{Ar} /{ }^{39} \mathrm{Ar}$ chronology of Early to Middle Miocene Upper Freshwater Molasse in eastern Bavaria (Germany). International Journal of Earth Sciences, 97:115-134.

Agustí J., Cabrera L., Garcés M., Krijgsman W., Oms O. \& Parés J. M. (2001). A calibrated mammal scale for the Neogene of Western Europe. State of the art. Earth Science Reviews, 52: 247-260.

Bowdich T. E. (1821). An Analysis of the Natural Classifications of Mammalia for the Use of Students and Travellers. Ed: J. Smith. Paris, 115 pp.

Casanovas-Vilar I., Madern A., Alba D. M., Cabrera L., García-Paredes I., Van den Hoek Ostende LW., DeMiguel D., Robles JM., Furió M., van Dam JA., Garcés M., Angelone C. \& Moyà-Solà S. (2016). The Miocene mammal record of the Vallès-Penedès Basin (Catalo- nia). Comptes Rendus Palevol, 15:791-812.

Daams R. (1976). Miocene rodents (Mammalia) from Cetina de Aragón (prov. Zaragoza) and Buñol (prov. Valencia), Spain. Proceedings of the Koninklijke Akademie van Wetenschappen B, 79: 152-182.

Fahlbusch V. (1964). Die Cricetiden (Mamm.) Der Oberen Sübwasser-Molasse Bayerns. Bayerische Akademie der Wissenschaften Mathematisch-Natur Wissenschaftliche Klasse Abhandlungen, 118: 4-136.

Fischer W. (1817). Adversaria zoologica. Mémories de la Société Impériale des Naturalistes de Moscou, 5: 357-471

Freudenthal M. (1963). Entwicklungsstufen der miozänen Cricetodontinae (Mammlia, Rodentia) Mittlespaniens und ihre stratigraphische Bedeutung [Succession of Miocene Cridetodontinae (Mammalia, Rodentia) in central Spain and their stratigraphic significance]. Beaufortia, 10:51-157.

Freudenthal M. (1967). On the Mammalian Fauna of the Hipparion-Beds in the Calatayud-Teruel Basin (Prov. Zaragoza, Spain). Part III. Democricetodon and Rotundomys (Rodentia). Proceedings of the Koninklijke Akademie van Wetenschappen, 70 (3): 298-315.

Freudenthal M. \& Daams R. (1988). Cricetidae (Rodentia) from the Type-Aragonian; the Genera Democricetodon, Fahlbuschia, Pseudofahlbuschia Nov. Gen., and Renzimys. In: Biostratigraphy and Paleoecology of the Neogene Micromammalian Faunas from the $\mathrm{Ca}$ latayud-Teruel Basin (Spain). Freudenthal M. (Eds). Scripta Geologica, Special Issue 1: 133-252.

Hilgen F. J., Lourens L. J. \& Van Dam J. A. (2012). The Neogene period. In Gradstein FM, Ogg JG, Schmitz M \& Ogg G. (eds), The geologic time scale. Elsevier, Amsterdam: 923-978.

Jovells-Vaqué S., Ginestí M. \& Casanovas-Vilar I. (2017). Cricetidae (Rodentia, Mammalia) from the early Miocene site of els Casots (Vallès-Penedès Basin, Catalonia). Fossil Imprint, 73: 141-154.

Jovells-Vaqué S., García-Paredes I., Furió M., Angelone C., Van den Hoek Ostende LW., Berrocal Barberà M., DeMiguel D., Madurell-Malapeira J. \& Casanovas-Vilar I. (2018). Les Cases de la Valenciana, a new early Miocene small-mammal locality from the Vallès-Penedès Basin (Catalonia, Spain). Historical Biology, 30: 404-421.

Kälin D. \& Kempf O. (2009). High-resolution stratigraphy from the continental record of the Middle Miocene Northern Alpine Foreland Basin of Switzerland. Neues Jahrbuch für Geologie und Paläontologie - Abhandlungen, 254: 177-235.

Prieto J. \& Rummel M. (2016). Some considerations about the small-mammal evolution in South Germany, with emphasis on late Burdigalian-earliest Tortonian (Miocene) cricetid rodents. Comptes Rendus Palevol, 15 : 837854

Stehin H. G. \& Schaub S. (1951). Die Trigonodontie de simplicidentaten Nager. Schweizerische Palaontologische Abhandlung, 67: 1-385.

Thaler L. (1966). Les rongeurs fossiles du Bas-Languedoc dans leurs rapports avec I'histoire des faunes et la stratigraphie du Tertiaire d'Europe. Memoires du Museum National d'Histoire Naturelle, 17: 295 pp.

Thaler L. (1969). Rongeurs nouveaux de l'Oligocène moyen d'Espagne. Paleovertebrata, 2: 191-207

Van der Meulen A. J., Pélaez-Campomanes P. \& Daams R. (2003). Revision of Medium-Sized Cricetidae from the Miocene of the Daroca-Villafeliche Area in The Calatayud-Teruel Basin (Zaragoza, Spain). Coloquios de Paleontologia, 1: 385-441. 
Van der Meulen A. J., García-Paredes I., Álvarez-Sierra M. A., Van den Hoek Ostende L. W., Hordijk K., Oliver A. \& Peláez-Campomanes P. (2012). Updated Aragonian biostratigraphy: small mammal distribution and its implications for the Miocene European chronology. Manuscript received 10 July 2018 Received after revision 2 October 2018 Accepted 3 October 2018 Geologica Acta, 10: 159-179. 